\title{
UPAYA PEMERINTAH DALAM MENGATASI KONFLIK SOSIAL DI PEKON SUKARAJA KECAMATAN SEMAKA KABUPATEN TANGGAMUS
}

\author{
Henni Kusumastuti ${ }^{1 *}$,Lies Kumara Dewi ${ }^{2}$ Eka Ubaya Taruna Rauf ${ }^{3}$ \\ Universitas Sang Bumi Ruwa Jurai \\ hennirek19@gmail.com
}

\begin{abstract}
Abstrak
Konflik yang terjadi di Pekon Sukaraja Kecamatan Semaka Kabupaten Tanggamus disebabkan oleh perbedaan pendirian, budaya dan juga faktor kepentingan. Pemerintah melakukan mediasi kepada kedua pihak, dan memberikan solusi terhadap permasalahan yang menjadikan konflik diantara kedua pihak. Seperti halnya Konflik yang terjadi di Pekon Sukaraja Kecamatan Semaka Kabupaten Tanggamus. Pihak yang berkonflik yaitu antar warga Pekon Sukaraja (Suku Jawa) dengan warga Pekon Karang Agung (Suku Lampung) yang terjadi di Pekon Sukaraja Kecamatan Semaka Kabupaten Tanggamus Provinsi Lampung. Konflik terjadi Pada hari Rabu tanggal 30 bulan Juli tahun 2014, tepatnya pada hari ketiga perayaan Idul fitri. Konflik tersebut mengakibatkan beberapa orang meninggal di karenakan kesalah pahaman dan aksi main hakim sendiri yang dikarenakan aksi pencurian motor. Akibatnya masyarakat dari kedua Pekon tersebut berkonflik secara fisik. Tujuan penelitian untuk mengetahui bagaimana upaya Pemerintah dalam mengatasi konflik sosial yang terjadi di Pekon Sukaraja Kecamatan Semaka Kabupaten Tanggamus. Teknik pengumpulan data yang digunakan observasi, wawancara dan dokumentasi, analisis data yang digunakan analisis kualitatif. Hasil penelitian dan pembahasan diketahui bahwa penyebab konflik sosial yang terjadi di Pekon Sukaraja dikarenakan masih adanya perbedaan pendirian, budaya dan juga faktor kepentingan. Namun secara umum hubungan (integrasi) sosial antara masyarakat Sukaraja dan Karang Agung di Kecamatan Semaka Kabupaten Tanggamus berjalan dengan baik. Hal itu ditandai dengan tingginya intensitas interaksi sosial antar masyarakat, tidak terjadi jarak sosial dan upaya menjaga keamanan dan harmoni bersama. Interaksi dan kerjasama antara masyarakat berjalan dengan baik. Kesadaran masyarakat untuk hidup bersama sudah terlihat dari mereka, sikap mereka yang menerima dan manghargai perbedaan-perbedaan yang ada. Sedangkan upaya pemerintah dalam mengatasi konflik yang terjadi di Pekon Sukaraja diketahui bahwa tingkat keberhasilan upaya pemerintah terlihat dari beberapa proses yang dilalui di dalam masyarakat seperti: konsolidasi, mediasi dan arbitrasi. Proses tersebut terwujud terutama upaya mediasi ditengah-tengah masyarakat yang berkonflik. Melalui proses mediasi tersebut masyarakat terintegrasitas dan menjadi satu kesatuan sistem. Nilai dan norma yang menjadi acuan dasar individu dalam menjalankan aktifitas sehari-hari di masyarakat.
\end{abstract}

Kata kunci : Upaya Pemerintah, Konflik Sosial

\begin{abstract}
The conflict that occurred in Pekon Sukaraja, Semaka District, Tanggamus Regency was caused by differences in stance, culture and also factors of interest. The government mediates between the two parties, and provides solutions to problems that cause conflict between the two parties. Like the conflict that occurred in Pekon Sukaraja, Semaka District, Tanggamus Regency. Parties to the conflict were between residents of Pekon Sukaraja (Javanese tribe) and residents of Pekon Karang Agung (Lampung Tribe) which occurred in Pekon Sukaraja, Semaka District, Tanggamus Regency, Lampung Province. The conflict occurred on Wednesday, 30 July 2014, to be precise on the third day of the Eid celebration. The conflict resulted in several people dying due to misunderstanding and vigilante actions due to motorbike theft. As a result, the people of the two Pekons were in physical conflict. The research objective was to determine how the Government's efforts to overcome social conflicts that occurred in Pekon Sukaraja, Semaka District, Tanggamus Regency. Data collection techniques used observation, interviews and documentation, data analysis used qualitative analysis. The results of the research and discussion showed that the causes of social conflict that occurred in Pekon Sukaraja were due to differences in stance, culture and also factors of interest. However, in general the social (integration) relationship between the people of Sukaraja and Karang Agung in Semaka District, Tanggamus Regency is going well. This is indicated by the high intensity of social interaction between communities, no social distancing and efforts to maintain security and harmony together. The interaction and cooperation between the community is going well. Community awareness to live together can be seen from them, their attitude to accept and respect the differences that exist. Meanwhile, the government's efforts to resolve the conflict that occurred in Pekon Sukaraja, it is known that the level of success of the government's efforts can be seen from several
\end{abstract}


Seminar Nasional Penelitian dan Pengabdian kepada Masyarakat

Universitas Sang Bumi Ruwa Jurai Tahun 2020

processes that have been passed in the community, such as: consolidation, mediation and arbitration. This process is manifested primarily in mediation efforts in the midst of conflicted communities. Through the mediation process, the community is integrated and becomes a unified system. Values and norms that become the basic reference for individuals in carrying out daily activities in society.

Keywords: Government Efforts, Social Conflict

\section{PENDAHULUAN}

Beragam konflik yang terjadi di Indonesia diantaranya konflik-konflik yang berlatar belakang kesukuan seperti yang terjadi di Kalimantan Barat, Kalimantan tengah, Solo, dan Nusa Tenggara Barat. Konflik yang berlatar belakang keagamaan juga terjadi di Poso dan Ambon. Baru-baru ini konflik yang masih berlatar belakang kesukuan juga terjadi di Kabupaten Lampung Selatan.

Persoalaan konflik termasuk masalah yang menyangkut kepentingan publik (keamanan), dimana memahami peran pemerintah dalam merespon persoalaan publik adalah sesuatu yang sangat penting. Kemampuan pemerintah dalam menyelesaikan permasalahan publik menjadi titik tekan kredibilitas pemerintah dalam pengelolaan konflik yang setiap waktu dapat terjadi. Maka dari itu kehadiran negara mutlak diperlukan dalam penangan konflik yang terjadi di daerah lokal dalam menjaga bingkai Negara Kesatuan Republik Indonesia.

Surbakti dalam Putra, (2017:12) berpendapat bahwa "Konflik sering dimaknai berupa benturan seperti perbedaan pendapat, persaingan atau pertentangan antara individu dengan individu, individu dengan kelompok, kelompok dengan kelompok, serta antara individu atau kelompok dengan pemerintah".

Konflik dapat muncul dalam berbagai latar seperti permasalahan antar individu maupun kelompok, baik yang menyangkut ekonomi, politik ataupun sosial budaya seperti stereotipe yang berarti berprasangka buruk terhadap suku lain.

Pada awalnya, demokrasi telah melahirkan respon keras masyarakat berupa tuntutan bagi adanya penyelenggaraan tata kelola pemerintah yang baik (good governance).

Menurut Utomo, (2017:21), government sebagai pemerintahan yang bertumpu kepada otoritas telah berubah ke governance yang bertumpu yang bertumpu kepada kompatibilitas, sehingga pemerintah tidak lagi menjadi pemain tunggal.

Memahami prinsip governance dalam pengelolaan konflik sendiri mengindikasikan adanya usaha perlibatan aktor atau lembaga non-negera dalam proses penyelesaian konflik. Dengan adanya penarikan oleh negara tersebut tentunya akan lebih melegitimasi masyarakat sipil (civil society) serta swasta (economic society) sebagai bagian integral governance dalam sebuah lingkup yang disebut sebagai "pemberdayaan" oleh negara, sehingga ada semacam kemitraan (partnership) antara negara (state) dan masyarakat (society) yang mengakibatkan makna administrasi publik berkembang menjadi kegiatan kemitraan (Nugroho, 2017:22).

Seiring dengan era desentralisasi dimana pemerintah pusat memberikan kewenangan kepada Pemerintah daerah untuk mengurus daerahnya secara mandiri, efektif dan efisien. Maka sangat penting untuk diterapkanya penyelesaian masalah dan pengambilan keputusan dengan mempertimbangkan partisipasi masyarakat (civil society) sebagai salah satu prinsip dalam good governance yang menjadi layak untuk dijalankan dalam proses penangan konflik lokal. Astrid Susanto, (2016:44)

Topik yang memfokuskan Negara dan konflik menarik untuk dikaji dikarenakan dalam kehidupan berbangsa dan bernegara, konflik mungkin tidak dapat dihindari. Interaksi yang beraneka ragam kepentingan baik secara ekonomi, politik dan sosial budaya dalam 
bernegara pada giliranya akan menimbulkan berbagai benturan dan gesekan hingga berujung kekerasan apabila tidak dikelola dengan baik. Elly M. Setiadi dan Usman Kolip, (2011:23)

Hal ini mempertegas bahwa konflik merupakan realitas yang normal dalam setiap interaksi yang terjadi. Sehingga dapat dikatakan kondisi damai merupakan masa sela diantara dua atau lebih konflik. Selain itu Negara yang dalam konteks ini direpresentasikan oleh pemerintah hampir selalu bertindak sebagai "pemadam kebakaraan" semata. Pemerintah baru bertindak setelah konflik meledak menjadi kekerasan atau kerusuhan massal, seolah olah pemerintah diam dan kecolongan. Padahal Pemerintah dapat berfungsi sebagai early respon system dalam setiap interaksi yang berpotensi konflik. Astrid Susanto, (2016:72)

Penelitian yang mencoba mengangkat tema konflik menjadi amat penting untuk mencegah dan memperbaiki hal-hal yang tidak diinginkan, dengan argumentasi kasus konflik yang terjadi seperti di Lampung Selatan tidak hanya mengakibatkan kerugian fisik namun juga dapat mengakibatkan kerugian non-fisik yang juga dapat digolongkan sebagai bencana sosial.

Bencana sosial memiliki karakteristik tersendiri dalam dampaknya seperti hilangnya modal sosial yang berbentuk trust, social values, networking dan yang lainya yang sebenarnya sangat berperan penting bagi proses berlangsungnya pembangunan di suatu daerah. Astrid Susanto, (2016:102)

Konflik yang terjadi secara terus menerus menjadi acaman serius akan terjadinya disintegrasi bangsa, sehingga di titik yang ekstrim dapat terjadi pemisahan wilayah dalam suatu Negara (separatis) dan ini mengancam keutuhan Bangsa Indonesia yang terangkum dalam Negara Kesatuan Republik Indonesia. Selanjutnya sebagai wilayah yang memiliki potensi ekonomi dan politik yang strategis konflik dapat menjadi penghambat pembangunan yang terjadi di daerah tersebut. Iklim usaha dan proses pemerintahan menjadi tidak kondusif untuk dijalankan dan akan berujung pada gagalnya pemenurunan kesejahteraan di masyarakat. Ayyub Siswanto, (2014:3)

Konflik antara suku Lampung yang notabene pribumi dengan suku Bali yang merupakan pendatang meletus hingga dua kali dalam setahun terakhir (2012). Konflik pertama meletus pada 24 januari 2012 terjadi antara Pekon Kota (Lampung) dalam dan Pekon Napal (Bali) kemudian konflik yang kedua terjadi pada 28 Oktober 2012 antara Pekon Agom (suku Lampung) dan Pekon Balinuraga (Bali). Menurut sumber yang diberitakan permasalahan yang ditimbulkan tergolong masalah yang kecil seperti masalah motor di parkiran (konflik pertama) dan diganggunya pemudi Pekon agom oleh pemuda Pekon balinuraga sehingga menyebabkan terjatuh dari motor (konflik kedua). Dalam setahun terakhir intensitas konflik antara kedua etnik ini semakin meningkat. Sumber (Kesbangpol Kabupaten Tanggamus, Tahun 2020)

Konflik yang terjadi di Pekon Sukaraja Kecamatan Semaka Kabupaten Tanggamus disebabkan oleh perbedaan pendirian, budaya dan juga faktor kepentingan. Pemerintah melakukan mediasi kepada kedua pihak, dan memberikan solusi terhadap permasalahan yang menjadikan konflik diantara kedua pihak. Seperti halnya Konflik yang terjadi di Pekon Sukaraja Kecamatan Semaka Kabupaten Tanggamus. Pihak yang berkonflik yaitu antar warga Pekon Sukaraja (Suku Jawa) dengan warga Pekon Karang Agung (Suku Lampung) yang terjadi di Pekon Sukaraja Kecamatan Semaka Kabupaten Tanggamus Provinsi Lampung. Konflik terjadi Pada hari Rabu tanggal 30 bulan Juli tahun 2014, tepatnya pada hari ketiga perayaan Idul fitri. Kedua Pekon tersebut masuk dalam wilayah administrative Kecamatan Semaka Kabupaten Tanggamus. Secara geografis letak keduanya tidak terlalu berjauhan, jarak kedua Pekon hanya sekitar 5 kilometer. Konflik tersebut mengakibatkan beberapa orang meninggal di karenakan kesalah pahaman dan aksi main hakim sendiri. Akibatnya masyarakat dari kedua Pekon tersebut berkonflik secara fisik. (http:// www.lampunggeh.ga/2020/04/kapolres-tanggamus-kerusuhan-dipicu-isu.html) 
Merespon kejadian konflik yang terus berulang bahkan dengan tingkat eskalasi konflik yang makin meluas. Pemerintah dalam hal ini telah menerbitkan Undang-Undang Nomor 7 tahun 2012 tentang Penanganan Konflik Sosial. Dalam Undang-undang tersebut secara jelas disebutkan untuk mencegah konflik yang terjadi harus adanya kerjasama antara Pemerintah baik Pusat maupun Pemerintah Daerah dan masyarakat yang tertulis pada Pasal 6 ayat 2. Akan tetapi apabila dicermati regulasi ini masih belum cukup terutama untuk teknis pedoman semua pihak untuk menyelesaikan konflik. Seperti yang dilontarkan oleh Eva Kusuma Sundari, anggota komisi III DPR RI.

Yang menjadi problem dengan UU No.7/2012 tentang Penanganan Konflik Sosial (PKS) memang belum adanya peraturan pemerintah (PP). Namun, jangan sampai penerapannya di tengah masyarakat terhambat gara-gara belum ada PP-nya. (http//www.buletininfo.com/news/ Implementasi UU Penanganan Konflik Sosial Jangan Terhambat PP .html / diakses 5 April 2020).

Permasalahan penanganan konflik sebaiknya tidak lagi menggunakan pendekatan security yang lebih bersifat top down. Lebarnya persoalaan konflik dengan kemampuan pemerintah yang terbatas untuk menyelesaikanya apalagi dengan metode kekerasan sering bermuara pada ketidakpercayaan masyarakat kepada pemerintah dalam menyelesaikan persoalaan konflik, pada titik yang lebih ekstrim cara ini dapat memicu delegitimasi peran dan posisi pemerintah yang dikontrak oleh publik untuk melaksanakan misi-misi publik. Berdasarkan pernyataan tersebut harus dibangun bagaimana cara penyelesaian konflik (resolusi konflik) yang muncul dari bottom-up yang secara damai dan melibatkan semua pihak. Sehingga kesadaran masyarakat untuk menjadi problem solving dalam konflik menjadi fokus perhatian dalam proses penyelesaian konflik. Ayyub Siswanto, (2014:112)

Pemberdayaan masyarakat oleh pemerintah mutlak diperlukan untuk meningkatkan kualitas dan kapasitas masyarakat dalam menangani masalah konflik secara swadaya. Penerapan model resolusi konflik yang sudah ada perlu untuk dikembangkan mengingat regulasi pemerintah terhadap penanganan konflik sosial masyarakat masih mencari bentuk terutama untuk peran masyarakat dalam membantu penanganan konflik sosial, sehingga arah resolusi konflik kedepan harus mampu menyelesaikan masalah secara komprehensif dan bervisi jangka panjang dengan legitimasi yang dapat diterima oleh semua pihak yang berkonflik. Astrid Susanto, (2016:97)

Berdasarkan latar belakang permasalahan yang sudah dijelaskan tersebut peneliti tertarik untuk melakukan penelitian dengan judul : "Upaya Pemerintah Dalam Mengatasi Konflik Sosial Di Pekon Sukaraja Kecamatan Semaka Kabupaten Tanggamus".

\section{METODE PENELITIAN}

Menurut Bogdan dan Taylor (dalam Moleong, 2013: hal. 4) mengemukakan bahwa: "Metodologi kualitatif merupakan prosedur penelitian yang menghasilkan data deskriptif berupa kata-kata tertulis maupun lisan dari orang-orang dan perilaku yang diamati". Adapun tahapan dimulai dari identifikasi masalah, perumusan masalah, tujuan dan kegunaan penelitian, mencari tinjauan pustaka yang akan peneliti gunakan kemudian menentukan metode penelitian yang dapat digunakan meliputi : menentukan subjek dan sumber informasi, pengumpulan dan pengolahan data analisis data serta penetapan kesimpulan dimana proses mencari pemecahan masalah secara sistematis dengan menggunakan metode ilmiah serta aturaan-aturan yang berlaku.

Fokus penelitian dalam penelitian ini adalah bagaimana upaya pemerintah dalam mengatasi konflik yang terjadi di Pekon Sukaraja Kecamatan Semaka Kabupaten Tanggamus. Dengan upaya pemerintah mengatasi masalah konflik dengan :

1. Konsiliasi (conciliation) 
Pengendalian semacam ini terwujud melalui lembaga-lembaga tertentu yang memungkinkan tumbuhnya pola diskusi dan pengambilan keputusan-keputusan diantara pihak-pihak yang berlawanan mengenai persoalan-persoalan yang mereka pertentangkan.

2. Mediasi (mediation)

Bentuk pengendalian ini dilakukan bila kedua belah pihak yang bersengketa bersamasama sepakat untk memberikan nasihat-nasihatnya tentang bagaimana mereka sebaiknya menyelesaikan pertentangan mereka.

3. Arbitrasi berasal dari kata latin arbitrium, artinya melalui pengadilan, dengan seorang hakim (arbiter) sebagai pengambil keputusan. Arbitrasi berbeda dengan konsiliasi dan mediasi. Seorang arbiter memberi keputusan yang mengikat kedua belah pihak yang bersengketa, artinya keputusan seorang hakim harus ditaati. Apabila salah satu pihak tidak menerima keputusan itu, ia dapat naik banding kepada pengadilan yang lebih tinggi sampai instansi pengadilan nasional yang tertinggi.

Adapun penyebab terjadinya konflik dikarenakan :

1. Perbedaan Pendirian

Pendapat (keyakinan) yang dipakai tumpuan untuk memandang atau mempertimbangkan sesuatu.

2. Perbedaan Budaya

Bahwa budaya itu merupakan cipta batin (akal budi) suatu masyarakat, sedangkan kebudayaan merupakan hasil kegiatan dan penciptaan budaya masyarakat tersebut seperti kepercayaan

3. Perbedaan Kepentingan

Suatu hal yang dimiliki atau yang timbul dalam diri manusia itu sendiri, hal tersebut dapat menjadi ciri khas dari seseorang.

Agar tidak melebar pembahasan dalam penelitian ini, maka penulis membatasi ruang lingkup dalam penelitian ini yaitu ; mencari sebab terjadinya konflik di Pekon Sukaraja Kecamatan Semaka Kabupaten Tanggamus serta upaya Pemerintah dalam menangani konflik yang terjadi di Pekon Sukaraja Kecamatan Semaka Kabupaten Tanggamus.

Subyek penelitian ini adalah peneliti aparat pemerntah dan masyarakat, namun selanjutnya setelah fokus penelitian menjadi jelas maka kemunginan akan dikembangkan instrument penelitian sederhana, yang diharapkan dapat melengkapi dan membantu peneliti dalam pengumpulan data. Ada 5 (lima) orang yang dijadikan sumber informasi oleh peneliti.

Teknik Pengumpulan Data

1. Wawancara

Wawancara adalah teknik pengumpulan data yang digunakan untuk mendapatkan keterangan-keterangan lisan melalui percakapan dan berhadapan langsung dengan objek. Dalam penelitian ini menggunakan teknik wawancara terstruktur kemudian berkembang menjadi wawancara tidak terstruktur. Wawancara terstruktur adalah wawancara yang pewawancaranya, dalam hal ini peneliti menetapkan sendiri masalah dan pertanyaan yang diajukan. Artinya bahwa wawancara terstruktur digunakan sebagai teknik pengumpulan data, bila peneliti telah mengetahui dengan pasti tentang informasi apa yang diperoleh. Oleh karena itu dalam melakukan wawancara, peneliti harus menyiapkan instrument penelitian berupa pertanyaan-pertanyaan tertulis yang alternatif jawabannya pun telah disiapkan. Sedangkan wawancara tidak tersteruktur adalah wawancara yang bebas dimana peneliti tidak menggunakan pedoman wawancara yang telah tersusun secara sistematis dan lengkap untuk pengumpulan data.Wawancara tidak terstruktur sering digunakan dalam penelitian pendahuluan atau melainkan penelitian yang telah mendalam tentang subjek yang diteliti. Untuk mendapatkan informasi yang manedalam tentang responden, maka 
Seminar Nasional Penelitian dan Pengabdian kepada Masyarakat

Universitas Sang Bumi Ruwa Jurai Tahun 2020

peneliti dapat juga menggunakan teknik wawancara tidak terstruktur. (Sugiono, 2013:233).

Adapun alat bantu yang dapat digunakan dalam proses pengumpulan data dengan teknik wawancara adalah berupa: tape recorder, gambar, kamera, dan lain-lain yang dapat digunakan oleh peneliti dalam pengumpulan data.

2. Observasi

Observasi atau pengamatan merupakan salah satu teknik pengumpulan data dengan jalan mengamati dan mencatat secara cermat dan sistematis terhadap objek yang secara langsung. Dalam penelitian ini menggunakan teknik observasi pertisipatif, dalam observasi ini, peneliti terlibat dengan kegiatan sehari-hari orang yang sedang diamati atau yang digunakan sebagai sumber data penelitian. (Sugiono, 2013: hal. 227).

3. Dokumentasi

Teknik dokumentansi dalam penelitian kualitatif bertujuan untuk meningkatkan kredibilitas atau derajat kepercayaan dari hasil penelitian, yang dapat berupa gambar, maupun catatan-catatan lapangan yang penting menyangkut dengan objek penelitian.

Adapun teknik analisis data yang digunakan dalam penelitian ini adalah analisis kualitatif. Menurut Miles dan Huberman (1994: hal. 23), yang meliputi reduksi data, penyajian, verifikasi data atau penarikan kesimpulan.

\section{Reduksi Data}

Data yang diperoleh di lapangan penelitian dituangkan dalam uraian atau laporan yang lengkap dan terperinci. Kemudian laporan tersebut direduksi dan memilih data-data kemudian dipilih data yang relevan untuk dikaji berdasarkan fokus dalam penelitian.

2. Penyajian data

Penyajian data menggambarkan secara keseluruhan data penelitian. Data yang dikaji dalam penelitian disesuaikan dengan data di lapangan dan informasi yang diperolah melalui responden.

3. Verifikasi data/penarikan kesimpulan

Penarikan kesimpulan dilakukan sejak awal penelitian langsung hingga pada akhirnya. Penarikan kesimpulan ini dilakukan dengan mencari pola dan hubungan data yang relevan dengan fokus penelitian yang kemudian ditingkatkan di dalam kesimpulan akhir.

\section{HASIL DAN PEMBAHASAN}

Berdasarkan keterangan hasil wawancara tersebut diketahui bahwa penyebab konflik sosial di Pekon Sukaraja Kecamatan Semaka Kabupaten Tanggamus adalah konflik sosial merupakan fenomena dinamika yang tidak dapat dihindarkan dalam kehidupan masyarakat, bahkan konflik selalu hadir dalam setiap hubungan kerja antara individu dan kelompok. Konflik menurut definisi Coser adalah perselisihan mengenai nilai-nilai atau tuntutantuntutan berkenaan dengan status, kuasa dan sumber-sumber kekayaan yang persediaannya tidak mencukupi dimana pihak-pihak yang berselisih tidak hanya berselisih untuk memperoleh barang yang diinginkan melainkan juga memojokan atau menghancurkan lawan mereka. Penanganan konflik terkait dengan kapasitas seseorang menstimulasi konflik, mengendalikan konflik, dan mencari solusi pada tingkat yang optimum. Kemampuan yang diperlukan dalam rangka penanganan konflik ini terwujud dalam bentuk keluasan pandangan dan wawasan seseorang dalam memandang setiap persoalan, baik yang memiliki perbedaan, maupun yang sama dengan kerangka pemikirannya. Keterampilan penanganan konflik 
terwujud dalam bentuk pencarian solusi terhadap konflik-konflik yang terjadi sehingga tidak berdampak buruk terhadap individu maupun masyarakat.

Konflik yang terjadi di Pekon Sukaraja Kecamatan Semaka Kabupaten Tanggamus. Pihak yang berkonflik yaitu antar warga Pekon Sukaraja (Suku Jawa) dengan warga Pekon Karang Agung (Suku Lampung) yang terjadi di Pekon Sukaraja Kecamatan Semaka Kabupaten Tanggamus Provinsi Lampung. Konflik terjadi Pada hari Rabu tanggal 30 bulan Juli tahun 2014, tepatnya pada hari ketiga perayaan Idul fitri. Kedua Pekon tersebut masuk dalam wilayah administrative Kecamatan Semaka Kabupaten Tanggamus. Secara geografis letak keduanya tidak terlalu berjauhan, jarak kedua Pekon hanya sekitar 5 kilometer. Konflik tersebut mengakibatkan beberapa orang meninggal di karenakan kesalah pahaman dan aksi main hakim sendiri. Akibatnya masyarakat dari kedua Pekon tersebut berkonflik secara fisik

Bahwa awal mula kejadian tersebut yaitu seseorang yang bernama Kudai warga pekon Karang Agung Kecamatan Semaka, bersama rekannya tertangkap mencuri sepeda motor di sebuah Masjid yang pemiliknya sedang melaksanakan shalat maghrib. Syahyani alias Kudai tertangkap warga dan dihakimi oleh warga hingga tewas di Dusun Mojoroto Pekon Sukaraja. Sementara salah seorang rekannya yang ikut melakukan aksi pencurian motor berhasil kabur. Pada saat yang bersamaan salah seorang warga dari Pekon Padawaras bernama Reval sambil menuntun sepeda motor melintas disekitar lokasi dimana pelaku pencurian sedang dihakimi massa. Reval bermaksud menanyakan perihal kejadian tersebut. Warga menduga bahwa Reval merupakan rekan Syahyani yang berhasil kabur dan berpurapura bertanya, massa itu pun akhirnya memukuli Reval. Reval ikut menjadi korban amuk massa oleh warga Pekon Sukaraja. Padahal antara Reval dan Syahyani tidak ada hubungan sama sekali.

Bermula dari aksi pencurian motor yang kemudian terjadi tindakan main hakim sendiri serta salah paham tersebut yang mengakibatkan terjadinya penyerbuan ke Pekon Sukaraja oleh Pekon karang agung yang ada di Kecamatan Semaka, massa tidak terima terhadap tindakan Pekon Sukaraja yang main hakim sendiri memukuli syahyani alias kudai. Aksi pengrusakan dan pembakaran rumah warga Sukaraja terjadi hingga tiga kali. Pertama terjadi sekitar pukul 19:00 WIB, aksi kedua pada pukul 21:00, dan yang ketiga pada hari kamis pukul 02:00"

Seperti halnya konflik yang terjadi di Pekon Sukaraja Kecamatan Semaka Kabupaten Tanggamus. Dari hasil penelitian dilapangan, menunjukkan bahwa terdapat berbagai macam alasan penyebab sehingga terjadilah konflik pekon tersebut. Berikut penyebab terjadinya konflik sosial di Pekon Sukaraja Kecamatan Semaka Kabupaten Tanggamus yang diungkapkan oleh informan diantaranya yaitu: perbedaan pendirian, perbedaan budaya, perbedaan kepentingan.

Bahwa satu pemicu terjadadinya konflik yaitu adanya perbedaan pendirian kurangnya pendapat (keyakinan) yang dipakai tumpuan untuk memandang atau mempertimbangkan sesuatu, berdasarkan hasil wawancara dan penelitian dilapangan yang dijelaskan oleh beberapa informan mengenai akar penyebab konflik secara lebih luas dan terperinci. Mereka berpendapat bahwa beberapa hal yang lebih mempertegas akar dari timbulnya konflik sosial di Pekon Sukaraja Kecamatan Semaka Kabupaten Tanggamus adalah perbedaan pendirian antar-individu: di antaranya perbedaan pendapat, tujuan, keinginan, pendirian tentang objek yang dipertentangkan. Di dalam realitas sosial tidak ada satu pun individu yang memiliki karakter yang sama sehingga perbedaan karakter tersebutlah yang mempengaruhi timbulnya konflik sosial.

Setiap masalah seperti konflik yang terjadi di Pekon Sukaraja tak luput dari perbedaan-perbedaan. Dalam hal ini perbedaan kebudayaan yang dimana kebudayaan Jawa dan kebudayaan Lampung. Ternyata perbedaan kepentingan bukanlah salah satu pemicu 
terjadinya konflik yang terjadi di Pekon Sukaraja, akan tetapi perbedaan kepentingan itu tidak dipungkii bahwa ada, akan tetapi hanya sebatas mencari kepentingan sendiri.

Fakta-fakta yang ditemukan menyangkut faktor-faktor penyebab konflik sesuai hasil wawancara dengan kepala pekon Sukaraja yaitu:

1. Disebabkan oleh pencurian sepeda motor yang dilakukan oleh warga karang agung terhadap warga sukaraja

2. Aksi main hakim sendiri yang dilakukan oleh beberapa warga sukaraja terhadap pencuri

3. Kesalah pahaman warga karang agung dalam menghakimi seseorang yang dikiranya teman pencuri ternyata tidak ada hubungan sama sekali dengan pelaku.

Kedua Kepala Pekon tersebut saling berkordinasi dan saling memberi masukan. Kebijakan kedua Kepala Pekon tersebut diharapkan dapat menghasilkan masyarakat yang sesuai dengan nilai-nilai dan norma-norma sosial. Sehingga terdapat penyesuaian normanorma yang konsisten dan dapat membentuk struktur masyarakat yang jelas. Fakta-fakta yang ditemukan menyangkut Faktor-faktor Penyebab Konflik antara warga Pekon Sukaraja dan warga pekon Karang Agung, adalah sebagai berikut:

1. Faktor penyebab utama tejadinya konflik antara masyarakat pekon sukaraja dengan masyarakat pekon karang agung disebabkan oleh perilaku pencurian sepeda motor yang di lakukan oleh salah satu warga karang agung tergadap warga sukaraja.

2. Peristiwa yang dianggap memicu konflik antara masyarakat pekon sukaraja dengan masyarakat pekon karang agung adalah peristiwa main hakim sendiri yang dilakukan oleh sekumpulan warga sukaraja sehingga menyebabkan kematian oleh pelaku pencuri sepeda motor.

Hasil penelitian yang dilakukan peneliti mengenai upaya pemerintah sudah sesuai dengan teori Nasikun (2013:22-25) mengatakan bahwa bentuk penyelesaian konflik yang lazim dipakai, yakni konsiliasi, mediasi, arbitrasi. Urutan ini berdasarkan kebiasaan orang mencari penyelesaian suatu masalah, yakni cara yang tidak formal lebih dahulu, kemudian cara yang formal, jika cara pertama membawa hasil. Menurut Nasikun, bentuk-bentuk pengendalian konflik yaitu secara umum ada tiga macam bentuk pengendalian bentuk pengendalian konflik sosial.

a. Konsiliasi

Bentuk pengendalian konflik seperti ini dilakukan melalui lembaga-lembaga tertentu yang memungkinkan diskusi dan pengambilan keputusan yang adil di antara pihak-pihak yang bertikai.

b. Mediasi

Pengendalian konflik dengan cara mediasi dilakukan apabila kedua pihak yang berkonflik sepakat untuk menunjuk pihak ketiga sebagai mediator. Pihak ketiga ini akan memberikan pemikiran atau nasihat-nasihatnya tentang cara terbaik menyelesaikan pertentangan mereka. Sekalipun pemikiran atau nasihat pihak ketiga tersebut tidak mengikat, namun cara pengendalian ini kadang-kadang menghasilkan penyelesaian yang cukup efektif. Cara seperti ini efektif mengurangi irasional yang biasanya timbul didalam konflik. Dengan cara seperti ini pula memungkinkan pihak-pihak yang berkonflik akan menarik diri tanpa harus "kehilangan muka".

c. Arbitrasi

Arbitrasi atau perwasitan umumnya dilakukan apabila kedua belah pihak yang berkonflik sepakat untuk menerima atau hdirnya pihak ketiga yang akan memberikan keputusankeputusan tertentu untuk menyelesaikan konflik yang terjadi diantara mereka 
Seminar Nasional Penelitian dan Pengabdian kepada Masyarakat

Universitas Sang Bumi Ruwa Jurai Tahun 2020

\section{KESIMPULAN}

Berdasarkan hasil penelitian dan analisa yang dilakukan dalam penelitian ini dapat disimpulkan sebagai berikut :

1. Upaya Pemerintah dalam mengatasi konflik yang terjadi di Pekon Sukaraja Kecamatan Semaka Kabupaten Tanggamus berdasarkan hasil penelitian diketahui bahwa tingkat keberhasilan upaya pemerintah terlihat dari beberapa proses yang dilalui di dalam masyarakat seperti: konsolidasi, mediasi dan arbitrasi. Proses tersebut terwujud terutama upaya mediasi ditengah-tengah masyarakat yang berkonflik. Melalui proses mediasi tersebut masyarakat terintegrasitas dan menjadi satu kesatuan sistem. Nilai dan norma yang menjadi acuan dasar individu dalam menjalankan aktifitas sehari-hari di masyarakat.

2. Penyebab konflik sosial yang terjadi di Pekon Sukaraja Kecamatan Semaka Kabupaten Tanggamus berdasarkan hasil penelitian diketahui bahwa adanya perbedaan pendirian, budaya dan juga faktor kepentingan. Namun secara umum hubungan (integrasi) sosial antara masyarakat Sukaraja dan Karang Agung di Kecamatan Semaka Kabupaten Tanggamus berjalan dengan baik. Hal itu ditandai dengan tingginya intensitas interaksi sosial antar masyarakat, tidak terjadi jarak sosial dan upaya menjaga keamanan dan harmoni bersama. Interaksi dan kerjasama antara masyarakat berjalan dengan baik. Kesadaran masyarakat untuk hidup bersama sudah terlihat dari mereka, sikap mereka yang menerima dan manghargai perbedaan-perbedaan yang ada.

\section{UCAPAN TERIMA KASIH}

Diucapkan terima kasih kepada segenap pihak pihak yang terkait dalam terselesaikannya penelitian ini, namun tiada suatu karya besar tanpa berani memulainya dari sesuatu yang kecil oleh karena itu kritik dan saran yang bersifat membangun sangat diharapkan. Semoga amal baik yang Bapak, Ibu dan rekan rekan berikan mendapat pahala yang setimpal dari Allah SWT, Amin

\section{DAFTAR PUSTAKA}

Astrid Susanto. (2016). Pengantar Sosiologi Dan Perubahan Sosial. Bandung: Bina Cipta,

Bogdan dan Taylor dalam Moleong, J. Lexy. (2013). Metodologi Penelitian Kualitatif. Bandung: Remaja Rosdakarya Offset,

Elly M. Setiadi dan Usman Kolip. (2011) Pengantar Sosiologi Pemahaman Fakta dan Gejala Permasalahan Sosial: Teori, Aplikasi, dan Pemecahannya. Jakarta: Kencana Prenada Media Group,

Irving M. Zeitlin. (2018). Memahami Kembali Sosiologi. Yogyakarta. Gajah Mada University Press

J. Dwi Narwoko dan Bagong Suyanto. (2015) Sosiologi Teks Pengantar dan Terapan. Jakarta.Kencana Prenada Media Group,

Kamus Besar Bahasa Indonesia. (2015) Balai Pustaka, Jakarta. 
Seminar Nasional Penelitian dan Pengabdian kepada Masyarakat

Universitas Sang Bumi Ruwa Jurai Tahun 2020

Kusnadi. (2012). Masalah Kerja Sama, Konflik dan Kinerja. Malang:Taroda

Muhtar,Fathurrahman (2016). "Konflik Dalam Pengelolaan Lembaga, Nusa Tenggara Barat. Program Pasca Sarjana IAIN Sunan Ampel.

Moleong, Lexy J. (2013). "Metodologi Penilitian Kualitatif." PT. Remaja Bandung: Rosdakarya,

Nasikun. (2013). Sistem Sosial Indonesia. Jakarta:PT. Raja Grafindo Persada,

Nugroho. (2017). Politik Media Mengenai Prinsip Penerapan Sosial. Yogyakarta:

CV Ganda,

Robert Lawang. (2014), Buku Materi Pokok Pengantar Sosiologi Universitas Jakarta: Universitas Terbuka

Robert H. Lauer. (2011). Perspektif Tentang Perubahan Sosial. Jakarta.PT. Rineka Cipta

Siswanto, Ayyub. (2014). Peranan Pemerintah Daerah Dalam Mengatasi Konflik Antar Kelompok Di Kecamatan Sabbang Kabupaten Luwu Utara

Soerjono Soekanto. (2012), Sosiologi Suatu Pengantar. Jakarta:Rajawali Pers

Soetomo. (2015). Masalah Sosial dan Pembangunan. Jakarta: PT. Dunia Pustaka Jaya

Soerjono Soekanto (2013) Kamus Sosiologi. Jakarta: PT. Raja Grafindo Persada

Surbakti dalam Putra (2017). Memahami Ilmu Politik. Gramedia Indonesia, Jakarta

Sugiono. (2013). Metodologi Penelitian Administrasi. Bandung: Alfabeta

Undang-Undang No.7 tahun 2012 tentang Penanganan Konflik Sosial.

Utomo. (2017). Mewujudkan Tata Pemerintahan Lokal yang Baik (Local Good Governance). Jakarta : PT. Raja Grafindo Persada 